\title{
THE FORMATION OF NATIONAL IDENTITY IN PROCESS OF AESTHETIC EDUCATION OF YOUTH
}

\author{
A FORMAÇÃO DA IDENTIDADE NACIONAL EM PROCESSO DE EDUCAÇÃO \\ ESTÉTICA DA JUVENTUDE
}

\section{LA FORMACIÓN DE LA IDENTIDAD NACIONAL EN PROCESO DE EDUCACIÓN ESTÉTICA DE JUVENTUD}

\author{
Gulnara Ildarovna SAFINA ${ }^{1}$ \\ Taisiya Olegovna PUSHKAR ${ }^{2}$ \\ Lubov Markelovna $\mathrm{YAO}^{3}$ \\ Juliana Gennadievna EMANOVA ${ }^{4}$
}

\begin{abstract}
The paper discusses the issues of national identity, and patriotism formation by means of national art and folk culture, which can arouse love for the family, their home, their national and territorial community. To study the process of formation of national identity, a constructionist approach was made, within which a constructed phenomenon was considered. The identity system of modern youth was studied by compiling a test by $\mathrm{T}$. Kuhn and $\mathrm{T}$. MacPartland "Who Am I?". The test was offered to students of the Kazan National Research University (1997; 2012), and students of Kazan Federal University (2019). A tendency to increase the proportion of students who determined their national identity (Tatar man / Tatar woman, Russian man / Russian woman) was identified. The paper reveals specific examples of the methods of forming a national identity in the process of aesthetic education: the revival of folk art, since it is inextricably linked with national and religious traditions; familiarization with the arts and crafts, reflecting the distinctive features of each nation. All the peoples of the Middle Volga live in Tatarstan: except for Tatars and Russians, the Chuvash, Mari, Mordovians, Ukrainians, Belarusians live in the republic. All nationalities of the republic have constructed their institutional formations, or cultural-national communities, spent their holidays, which go beyond the framework of the republic and become all-Russian and international.
\end{abstract}

KEYWORDS: Youth. National identity. Aesthetic education. National art. Popular culture. Aesthetic values.

RESUMO: $O$ documento discute as questões da identidade nacional e da formação do patriotismo por meio da arte nacional e da cultura popular, que são capazes de despertar o

${ }^{1}$ Kazan Federal University (KPFU), Kazan - Russia. Assistant of the Department of Design and National Arts. ORCID: https://orcid.org/0000-0002-2367-8581. E-mail: gulnara89119824693@yandex.ru

${ }^{2}$ Manhattan School of Music (MSM), New York - United States of America. Head of Instrumental Department. Doctor of Music. ORCID: https://orcid.org/0000-0003-4201-0541. E-mail: taisiyapushkar@gmail.com

${ }^{3}$ Kazan Federal University (KPFU), Kazan - Russia. Professor of the Department of Design and National Arts. Doctor of Sociology. ORCID: https://orcid.org/0000-0002-0647-1298. E-mail: yao lubov@mail.ru

${ }^{4}$ Kazan Federal University (KPFU), Kazan - Russia. Associate Professor of the Department of Design and National Arts. Candidate of Pedagogical Sciences. ORCID: https://orcid.org/0000-0001-8143-203X. E-mail: emanova-yao@mail.ru

RPGE- Revista on line de Política e Gestão Educacional, Araraquara, v. 25, n. esp. 1, p. 600-609, mar. 2021. e-ISSN:1519-9029 DOI: https://doi.org/10.22633/rpge.v25iesp.1.15000 
amor pela família, lar, comunidade nacional e territorial. Para estudar o processo de formação da identidade nacional, foi adotada uma abordagem construcionista, dentro da qual foi considerado um fenômeno construido. O sistema de identidade da juventude moderna foi estudado através da compilação de um teste por T. Kuhn e T. MacPartland "Quem sou eu?". O teste foi oferecido a estudantes da Universidade Nacional de Pesquisa de Kazan (1997; 2012), e a estudantes da Universidade Federal de Kazan (2019). Foi identificada uma tendência para aumentar a proporção de estudantes que determinaram sua identidade nacional (homem tártaro / mulher tártara, homem russo / mulher russa). O trabalho revela exemplos específicos dos métodos de formação de uma identidade nacional no processo de educação estética: o renascimento da arte popular, uma vez que ela está inextricavelmente ligada às tradições nacionais e religiosas; a familiarização com as artes e oficios, refletindo as características distintivas de cada nação. Todos os povos do Volga Médio vivem no Tartaristão: exceto Tártaros e Russos, os Chuvash, Mari, Mordovianos, Ucranianos, Bielorrussos vivem na república. Todas as nacionalidades da república formaram suas formações institucionais, ou comunidades culturais-nacionais, passam suas férias, que vão além da estrutura republicana e se tornam todas russas e internacionais.

PALAVRAS-CHAVE: Juventude. Identidade nacional. Educação estética. Arte nacional. Cultura popular. Valores estéticos.

RESUMEN: El trabajo discute los temas de la identidad nacional y la formación del patriotismo a través del arte nacional y la cultura popular, que son capaces de despertar el amor por la familia, su hogar, su comunidad nacional y territorial. Para estudiar el proceso de formación de la identidad nacional se tomó un enfoque construccionista, dentro del cual se consideró un fenómeno construido. El sistema de identidad de la juventud moderna se estudió compilando una prueba de T. Kuhn y T. MacPartland" ¿Quién soy yo?" La prueba se ofreció a estudiantes de la Universidad Nacional de Investigación de Kazán $(1997,2012)$ y a estudiantes de la Universidad Federal de Kazán (2019). Se identificó una tendencia a incrementar la proporción de estudiantes que determinaron su identidad nacional (hombre tártaro / mujer tártara, hombre ruso / mujer rusa). El artículo revela ejemplos específicos de los métodos de formación de una identidad nacional en el proceso de educación estética: el resurgimiento del arte popular, ya que está indisolublemente ligado a las tradiciones nacionales y religiosas; familiarización con las artes y oficios, reflejando las características distintivas de cada nación. Todos los pueblos del Volga Medio viven en Tartaristán: a excepción de los tártaros y los rusos, los chuvasos, los mari, los mordovianos, los ucranianos y los bielorrusos viven en la república. Todas las nacionalidades de la república han formado sus formaciones institucionales, o comunidades cultural-nacionales, pasan sus vacaciones, que van más allá del marco de lo republicano y se vuelven totalmente rusas e internacionales.

PALABRAS CLAVE: La juventud. Identidad nacional. Educación estética. Arte nacional. Cultura popular. Valores estéticos.

\section{Introduction}

The concept of identity (from the Latin word "Identificare", which means "to identify") is understood as the sameness of a subject or object with itself by meaningful 
awareness of the continuity and connectedness of its changeable basis. F. Brentano considered that "Identity is conformity conceivable in its perfection," (THE LATEST SOCIOLOGICAL DICTIONARY, 2010, p. 344). The very concept of "identity" was introduced into scientific circulation by Sigmund Freud; it describes the mechanism of internalization during the formation of a Super-Ego, and Erich Erickson in his work "Identity, Youth and Crisis" (1969) associated identity with an individual's recognition of himself as an integrity at each stage of cultural becoming. Modern Russian society is experiencing the emergence of a new social subjectivity. According to L.G. Ionin, who studied the role of culture in modern society, "national identity is a completely constructed phenomenon" (IONIN, 2004, p. 207). A constructionist approach to social problems arose in Western sociology in the 70 s of the twentieth century. The main ideas of this approach were formulated by Malcolm Spector and John Kitsuse in the construction of social problems: "social problems are that people consider social problems. An indication of a social problem as an indicator of social pathology, or vice versa, is just the application of two terms to the same subject" (SPECTOR; KITSUSE, 1977, p. 76). This approach places the responsibility for the emergence of social problems on the authorities, the media, and civil society institutions, since it is in the public discourse where the problem receives recognition, legitimacy, scientific justification, and public support. The mythologisation of social life also serves this. Myth is a way of functioning world outlook constructs in which conditional and indemonstrable speculative phenomena are perceived by individuals as truly existing elements of reality.

\section{Methods}

The study of the problems concerning the formation of national identity in the process of aesthetic education of youth was studied using methods such as the tests by T. Kuhn and T. MacPartland "Who Am I?", and analysis of reporting documentation of national district leisure centres in the Republic of Tatarstan (Russian Federation). The test was offered to students of Kazan National Research University (1997; 2012), and students of Kazan Federal University (2019).

\section{Results and discussion}

One of the myth's functions is to form and reproduce the identity of a collective, which was realized through the norms and values that unite community members and unite 
ideas and actions. So, for example, in the Soviet period, the myth of the flourishing of each individual nation within the Soviet country and at the same time the convergence of all nations, and the formation of a new historical community called the "Soviet people" (POLITIZDAT, 1979, p. 277). was "scientifically substantiated" and promoted in practice. It was argued that in a future communist society there will be a complete merger of nations; a common language will arise; common features of the spiritual appearance of people absorbing all the best from the national character traits of each people will be formed (POLITIZDAT, 1979 , p. 278). In the country of victorious socialism, there were no national problems, no one set out to form a national identity among the younger generations; on the contrary, they formed internationalism and fought with the "remnants" of nationalism. However, this did not mean that people completely lost their national identity. For example, in 1997 and 2012 the author conducted studies devoted to the system of social identities of student youth at Kazan State Technological University. Among 78 respondents who completed the test of T. Kuhn and T. MacPartland "Who Am I?", in 1997 national identity met 3 times, but after 15 years, in 2012, 33 students among 52 respondents noted their nationality: "Russian man / Russian woman", “Tatar man / Tatar woman". In 2019, 18 people out of 36 respondents among the students of Kazan Federal University named their nationality.

National identity is a reflection in the subjective context of the existing national indicators of public life, the conscious attitude of each nationality to its own nationality and international interaction. The concept of national identity is erroneously regarded as the usual assignment of individuals to different nationalities. This is a multifunctional system that includes stereotypical components, territorial knowledge, storage and transmission of historical roots, language and cultural heritage. According to some scholars, national identity is determined by the self-affirmation of a nation as a truly existing bearer of values of material and spiritual nature through their own awareness of belonging to a particular ethnic group. A number of scientists are of the opinion that the components of national identity are:

A conscious understanding by the nation and its representatives of the unity of their origin and their own socio-ethnic community;

Understanding and awareness of achievements for the good of the motherland and the accumulated representatives of the nation;

Understanding of own national interests and needs. 
A conscious understanding by a personality of one's own ethnogenesis is a stable element of this complex structure. Belonging to one or another ethnic group exists as a thought that has strengthened throughout life. However, other elements of the structure can often change and even disappear: a respectful attitude to traditions, habits, ritual processes, and love for the culture of one's ethnic group, history, heroes, and heroic countrymen.

In the absence of a national identity, it is impossible to talk about national identity that performs important functions:

Cognitive, the essence of which is the awareness of one's own difference from other nationalities, the allocation of own special "we", and own reality. Thanks to the cognitive function, the gaps in the evolutionary self-consciousness of an ethnic group are minimized; the spirituality of a nationality increases; the optimal functioning of national selfconsciousness without this function is not achievable;

Emotional-value, the essence of which is the directed formation of one's own attitude to the values of the nation, which are connected by emotions, moods and feelings of the people;

Regulatory, the essence of which is manifested in the achievement of a common goal thanks to the directed will of the ethnic group. Directions can be very diverse: achieving national independence, economic heights and social progress, maintaining and enhancing the highest values of the material and spiritual order. It is worth noting the main idea of national determination - the will to creative self-expression, self-affirmation and self-determination.

\section{Summary}

The formation of national identity is based on national culture. The myth of the flourishing of all nations under socialism had a real basis: all nations that did not have written language before the 1917 revolution, received it; illiteracy was completely eliminated in the country and all children received secondary education in Russian and their native language; there were theatres in their native languages in all national republics, newspapers and magazines, national philharmonic societies, song and dance ensembles, unions of artists, and writers. And nevertheless, the main negative aspects of life in the Soviet Union were sought precisely in the sphere of culture: people did not like the erasure of national differences, the oblivion of national traditions, national languages, national cuisine, and national religion. It was with these slogans that people went to rallies and demonstrations of protest, defended the 
radicalization of education not only in high school, but also in higher education, the formation of authorities on a national basis, and the strengthening of the national dimension in cultural life. It turned out that the artistic sphere of life is able to unite and solidate the nation, and a return to the origins, folk culture and folklore is more important than grandiose construction projects and the implementation of five-year plans (AHMETSHINA; KADYJROVA; MUSINA, 2016).

Three main components interact in the composition of the identity of a nation. Cognitive: understanding the fact of belonging to a certain nationality; value: positive and negative perception of the fact of identification with a group; emotional: accepted or unaccepted membership in a community as a result of the interaction of the first components.

The fact of understanding that a person belongs to a particular nation is caused by existing ideas about the foundations, principles and signs of identification of a particular community. Representations often use the image of a nation, which occupies a certain territory influencing the features of social interaction, the value views of a local population with its own cultural life, linguistic features and traditions formed over centuries. It follows from this that the foundations for national identity are cultural foundations and respect for traditions. It is no coincidence that folk art and folklore is now experiencing a "second" birth. In the cultural and leisure institutions of the Republic of Tatarstan, 9392 amateur groups are engaged in creative work, of which 893 are vocal and choreographic, whose national composition is made up of 493 groups of Tatar nationality (which is 55.2\%), including 49 of Kryashen nationality (which is 5.5\%), 46 Udmurt (5.2\%), 210 Russian teams $(23.5 \%)$, Chuvash teams in the amount of 108 units (12.1\%), Mari teams in the amount of 19 units $(2.1 \%) ; 15$ teams from representatives of Mordovian nationality $(1.7 \%)$ and 2 Ukrainian teams with a percentage ratio of $0.2 \% .11,389$ residents are engaged in creative activities; 10,041 villagers are involved in 815 collectives. 926 groups are occupied by folklore. Of these, 542 are Tatar (which is 56.5\%), 210 Russians (22.7\%), 100 Chuvash groups (10.8\%), 49 teams of Kryashen nationality (5.3\%), 38 Udmurt (which is $4.1 \%$ of the number of Tatar collectives), 19 Mari ensembles (2.1\%), as well as 15 Mordovian collectives (1.6\%) and 2 Ukrainian groups $(0.2 \%)$. Currently in the Republic of Tatarstan there are 501 members with the status of "an amateur folk group". This number includes 220 Tatar ensembles (43.9\%), of which $3.8 \%$ are occupied by 19 Kryashen folklore compositions, 2.4\% are Udmurt (12 units), 24.6\% are 123 Russian, 13 Mari (2.6\%), 28 Chuvash (5.6\%), 4 Ukrainian (0.8\%), 7 Mordovian (1.4\%), as well as 94 multinational groups with a multi-genre orientation, which amounted to $18.7 \%$. In April 2016, in the city of Octyabrsky, Republic of Bashkortostan, the 
folklore ensemble "Pryalitsa" created on the basis of the Bugulma House of Technology and consisting of representatives of Russian nationality took part at the inter-regional level in the Competition and Festival of Slavic Culture "Joy!" A folklore composition "Zhanashym" consisting of representatives of the Tatars from the Aznakaevsky district centre is the main organizer and participant of the international folklore festival "Chatyr tauda zhyen", which reveals the work of the Turkic peoples. The first festivals were held on a district scale, but later they went at an international level. Since 2013, the festival of Finno-Ugric peoples "We are branches of one tree" has been organized. They had a republican level; the main purpose of them was the preservation, maintenance, and development of folk genres of performers and traditions in the decorative and applied architecture of small peoples (Udmurts, Mordvins, Mari), and also increasing interest in their culture. It has become a tradition to organize events dedicated to the Day of the Native Language and the Day of the Russian Language. Competitions, seminars, and exhibitions are held on these dates by the institutions of art, culture and education. On these important days, the State Opera and Ballet Theatre named by M. Jalil invites guests to concert programs of masters of art in the Republic of Tatarstan. For 10 years in a row, the "Christmas Star" ("Tuym Zhondozy") has been held, which has the status of a festival that cannot do without a gala concert, where young fans of Kryashen motifs reveal their potential ${ }^{5}$.

\section{Conclusions}

Folklore activity increasingly occupies a leading place in various human activities, making it one of the important components of cultural heritage, gathering all the diversity of cultural spheres, both socially normative and material. Folklore has been accompanying mankind since its inception, being a part of culture, traditions, living conditions, ceremonies, and the whole life of community. In the past, it was the main source of the transfer of experience and the preservation of cultural and ideological values. Therefore, it is important to pay attention to the interconnectedness between the concepts of "folklore" and "popular identity". The dialectic of the relationship between these concepts is noted. Reflecting the interests of man, popular consciousness gained an independent foundation and became an important component of human spirituality (KARKINA et al., 2018). However, people's selfawareness is only one of the components of the people's consciousness and, at a certain period of their life, chooses different cultural values, thereby confirming their moving and changing

${ }^{5}$ Available: https://www.tatfolk.ru. Access: 10 dec. 2020.

RPGE- Revista on line de Política e Gestão Educacional, Araraquara, v. 25, n. esp. 1, p. 600-609, mar. $2021 . \quad$ e-ISSN:1519-9029 DOI: https://doi.org/10.22633/rpge.v25iesp. 1.15000 
foundation. Self-awareness captures folk culture from generation to generation, determines a person's attitude to cultural heritage, and reveals their significance in a specific period of time (YARMAKEEV; AKHMADULLINA; VALIAKHMETOVA, 2018). National self-awareness can be considered as certain cut in the history of traditional culture and an incentive for further cultural development. A prerequisite for the formation, maintenance and development of national consciousness is the assimilation of cultural values; it gives a national colour to the concept.

Arts and crafts carry the same burden. For example, the decorative art of the Kazan Tatars is closely connected with the life of the people, the originality of the national costume, and the character of the interior decoration. Along with geometric shapes, plant motifs are inherent in the ornament: simple petals of a modest flower, smoothly turning into complex compositional bouquets, as well as contouring, and free, often asymmetric, composition, and bright contrasting colours (MUHAMETZANOVA et al., 2018). Zoomorphic motifs are less commonly used. The patterns of Tatar masters were created during a long historical process and close communication with other multinational ethnic groups. The basis of the ornament is motifs depicting ancient agriculture closely associated with the local cultural heritage. Severe conditions for the creation of an ethnic group predetermined commonality in many areas of folk art. Embroidery is one of the oldest and most popular types of decorative art (DEPUTATOVA; EMANOVA; YAO, 2016). Such delicate needlework was developed during the times of female retreat and diversified home leisure. It was not customary for Tatars to use embroidery in decorating clothes. That is why they differed from Mari, Russians, and Ukrainians. But they preferred to embroider napkins, bedspreads, rugs for prayers (namazlyks), tablecloths, towels, and curtains. These things were widely used in the interiors of local dwellings. The national ornament of the Tatar ethnic group, which remains the main element of decorative and applied art, reflects the polysyllabic historical stages of the cultural formation and development of the nation. Each era in the life of the people left a certain imprint on the ornament, and its style. It should be noted that many motifs and patterns were widely used in the ornamental art of the Tatars. Depending on the technique of creating the ornament, its content and form have significant differences: the functional purpose of the product (decoration, towel, fence, etc.); placing the patterned row on the subject; choice of a colour scale (monocolour, multi-colour, alternation of tones). Widespread in Tatarstan are the folklore holidays of all the peoples inhabiting the republic. Such festivals as the Russian Karavon, Kuzminki, the Tatar Sabantuy, the Republican festival of Mordovian culture Baltai, which is celebrated a week after the Trinity, have gone beyond the borders of the republic. 
ACKNOWLEDGEMENTS: The work is performed according to the Russian Government Program of Competitive Growth of Kazan Federal University.

\section{REFERENCES}

AHMETSHINA, G. R.; KADYJROVA, L. H.; MUSINA, K. I. The use of virtual reconstruction technology to prepare intending designers in Kazan federal university. The Turkish Online Journal of Design, Art and Communication, n. esp., p. 3131-3140, 2016.

DEPUTATOVA, A.; EMANOVA, J.; YAO, M. Influence of art technologies on motivation of school students to studying world art culture. Modern Journal of Language Teaching Methods, n. 10, p. 59-64, 2016.

IONIN, L.G. Sociology of culture. Moscow: HSE Publishing House, 2004. 427 p.

KARKINA, S. V.; BATYRSHINA, G. I.; SAFIULLINA, L. G, KOVRIKOVA, E. V.; AGASARYAN, L. S. The sound imitation of some national instruments in piano music. Revista San Gregorio, n. 27, p. 6-13, 2018.

MUHAMETZANOVA, L.; PUSHKAR, T.; EMANOVA, J.; YAO, M. The contradiction between contemporary art demands and academic traditions of art education. National Academy of Managerial Staff of Culture and Arts Herald, v. 3, n. 2, 2018.

POLITIZDAT, M. Fundamentals of Marxist-Leninist philosophy. 4. ed. Textbook, 1979. $463 \mathrm{p}$.

RUSSIA. The official website of the Republican Center for the Development of Traditional Culture. Available: https://www.tatfolk.ru. Access: 10 dec. 2020.

SPECTOR, M.; KITSUSE, J. I. Constructing social problems. California: Menlo Park, 1977. p. 73-78.

THE LATEST sociological dictionary. Minsk: Book House, 2010. 344 p.

YARMAKEEV, I. E.; AKHMADULLINA, R. M.; VALIAKHMETOVA, N. R. Potential of pedagogical disciplines for forming ethno-cultural competence of students. Future teachers, Astra Salvensis, v. 6, p. 275-285, 2018. 


\section{How to reference this article}

SAFINA, G. I.; PUSHKAR, T. O.; YAO, L. M.; EMANOVA, J. G. The formation of national identity in process of aesthetic education of youth. Revista on line de Política e Gestão Educacional, Araraquara, v. 25, n. esp. 1, p. 600-609, mar. 2021. e-ISSN:1519-9029. DOI: https://doi.org/10.22633/rpge.v25iesp.1.15000

Submitted: 06/11/2020

Required revisions: $18 / 01 / 2021$

Approved: $23 / 02 / 221$

Published: 01/03/2021 